\title{
E-Commerce Transaction Mechanisms And Buyer-Supplier Relationship
}

Sungmin Ryu, Sungkyunkwan University, South Korea

Ken Hung, Suffolk University, USA

\begin{abstract}
Information exchange between the buyer and supplier is an important aspect of supply chain management. $B 2 B$ e-commerce helps firms to share information, maintain relationships, and conduct transactions more efficiently. The choice of B2B e-commerce transactions will influence, and as well as affect, the relationships between exchange parties. Thus, the choice of e-commerce transaction mechanisms has a relational context. An appropriate choice of a transaction mechanism can affect a firm's strategy, procurement decisions, and performance. It had been argued that e-commerce facilitates both discrete and relational exchanges, and it has a dual impact on business relationships. In this paper, we examine a collection of diverse studies on EDI and e-marketplace from marketing and information systems literatures. We assimilate these findings for managers considering choices on e-commerce transaction mechanisms. We hope that this will provide managers a more consistent understanding of buyer-supplier relationships in the B2B e-commerce context.
\end{abstract}

Keywords: EDI, e-Marketplace, Governance

\section{INTRODUCTION}

nformation about the marketplace such, as consumer tastes, demand patterns, and inventory, is one of the most valuable resources within a supply chain. Information exchange between the buyer and supplier constitutes an important dimension in supply chain management. Advancement in information technology, including telecommunication technology and database management technology, has greatly improved the exchange of information among firms in terms of the speed and clarity of communication. The primary impact of the Internet and web technology in supply chains has been to ensure that the right person has the right information at the right time (Krishnbamurthy 2002).

In the business-to-business (B2B) setting, electronic commerce (e-commerce) is the sharing of business information, maintaining business relationships, and conducting business transactions by digital means over public or private telecommunications networks. E-commerce is associated with forecasting, sales and procurement activities, product development collaboration, production planning, and inventory management. E-commerce can help supply chain management to share knowledge, increase the speed of response, and reduce the costs of servicing a market by improving information exchange between exchange parties (Boyle and Alwitt 1999; Lancioni, Smith et al. 2000; Krishnbamurthy 2002).

However, exchange parties taking on any from of e-commerce should consider the implications of ecommerce on the relationships between exchange parties and behavioral characteristics within the exchange relationships (Westland and Clark 1999). Interviews with researchers and senior managers on B2B e-commerce issues indicated that current progress of B2B e-commerce has been hindered by unanticipated technical, organizational, economic and legal challenges that diminish value (Dai and Kauffman 2002).

In this paper, we focus the relational aspect of interactions between e-commerce transactions and inter-firm relationships when firms engage in B2B e-commerce. Since 'relation' is a key factor differentiating relational exchange from market exchange (Heide 1994), we divide e-commerce into two groups according to transaction 
mechanisms: Electronic Data Interchange (EDI), and electronic marketplace (e-marketplace). While the Internet is sometimes used to refer to transactions other than EDI and e-marketplace transactions, we exclude the Internet as a transaction mechanism because of two reasons. We define the Internet as an information network on which emarketplace (or even some EDI) transactions take place. Also, from a relational aspect, Internet transactions can be considered as an extreme form of e-marketplace where the entire Internet is the marketplace.

Electronic Data Interchange (EDI) is a standard for the transmission of business documents, such as invoices, bills, and purchase orders, electronically using an agreed upon standard format. An EDI system allows linked computers to conduct business transactions of operational data (e.g. quantity, product type) over telecommunications networks such as intra-net or even the Internet. This can be more secure since partners use connections that cannot be accessed by anybody else. We used the term EDI transactions to refer to all business to business transactions conducted through an EDI system.

An electronic marketplace (e-marketplace) refers to an electronic trading facility that brings together registered buyers and suppliers for the purpose of providing commercial information and conducting transactions over the Internet. An e-marketplace may be public where there are many known buyers and suppliers with some level of information visibility, or it may be private. Marketplaces can be created by buyers, suppliers or third parties which may or may not be neutral. An e-marketplace depends on a critical mass of participants so that there is a liquid market. By getting access to a wide range of suppliers, a buyer can procure at a significant discount to their usual practices. We use the term e-marketplace transactions to refer to all business to business transaction conducted through some marketplace platforms, such as those provided by i2, or FreeMarkets by Ariba.

Some research had shown that a collaborative long-term relationship may not be suitable or feasible for all firms (Low 1996; Cannon and Perreault Jr 1999). A buyer may also maintain different forms of relationships with different suppliers (Dyer, Cho et al. 1998; Roberts and Mackay 1998; Bensaou 1999; Kaufman, Wood et al. 2000) because of different needs from various functional areas. Thus, the choice of e-commerce transaction mechanisms should also be relational context specific.

We believe that the choice of transaction mechanisms influences buyers' continuation and the nature of their relationship with their suppliers. The appropriate choice of transaction mechanisms can affect a firms' strategy, procurement decisions, and performance. How should firms choose their transaction mechanisms in e-commerce? How may this choice influence inter-firm relationships and their performances? Numerous and diverse studies on various different aspects on this issue have been done in the past. A summary that integrates findings from these studies will be valuable to managers considering choices on e-commerce transaction mechanisms. By understanding the factors influencing firms' choices on transaction mechanisms and the implications of these mechanisms on interfirm relationships, managers can manage their buyer-supplier relationships more effectively.

We conducted an extensive review of literature from marketing and information systems on the nature of the difference between e-commerce transaction mechanisms, including the relational aspect and the influencing factors on the performance of these mechanisms. We assimilated insights from these studies and constructed a summary framework for managers. In general, we took a buyer's perspective in analyzing and presenting these insights, but many of the benefits apply to both buyers and suppliers.

The rest of this paper is organized as followed. In section 2, we define the characteristics of EDI and emarketplace by summarizing relevant marketing and e-commerce literatures. We identify four categories of characteristics, ease of switching, level of information sharing, governance, and control mechanism. In section 3, we summarize relevant studies on the internal and external influences on buyers and suppliers in selecting transaction mechanisms. In section 4, we discuss three effects of choosing EDI or e-marketplace. Lastly, we present our summary in section 5 and the implications for managers.

\section{CHARACTERISTICS OF EDI AND E-MARKETPLACE}

E-commerce transactions have existed for a long time, but mainly in the form through private networks, such as EDI. Advancement of information technology in the last decade has introduced an alternative of e- 
commerce transaction, e-marketplace, through the Internet. Numerous studies on EDI help us understand its benefits and challenges. Popularization of the e-marketplace since the late 1990s has also spun some studies on its benefits and challenges. However, earlier studies before popularization of the e-marketplace focus mainly on information technology in general or EDI specifically. Recent studies focusing on e-marketplaces often do not include EDI or B2B (Bailey and Bakos 1997; Bakos 1998; Sarkar, Butler et al. 1998; Grieger 2003). So there is little direct comparison from e-commerce literatures on both transaction mechanisms.

For example, Bensaou investigated the different role of information technology in inter-organizational cooperation among US and Janpanese supplier relationships (Bensaou 1997). Raymond and Blili studied the role of EDI in forming the network enterprise, grouping of small and medium-sized subcontractors, suppliers, and distributors around a large pivot firm. They evaluated the subcontractors' potential for EDI adaptation considering external influences, predisposition of the organizational context, perception of EDI and business processes (Raymond and Blili 1997).

We surveyed literature from marketing and information systems on the nature of the difference ecommerce transaction mechanisms, including the relational aspect, and the influencing factors on the performance of these mechanisms. Since there are relatively few literatures on relational aspects discuss e-marketplace, we assimilate insights from these studies as they are applied to the e-marketplace. We present our summary in a layered approach. We start with the transaction characteristics of EDI and e-marketplace as enabled by information technology, followed by how governance and control characteristics can evolve from them.

Grewal, Comer et al. investigated the nature of firm participation in B2B e-marketplaces. The nature of participation is defined by organizational motivation, such a drive to efficiency, and ability, such as organizational learning and information technology capability. They concluded that both motivation and ability are important in determining the nature of participation; however, the level of influence of motivation and ability varies with the nature of participation (Grewal, Comer et al. 2001).

Past studies usually addressed the benefits of information technology and e-commerce in general. Ryssel, Ritter et al. studied that role of information technology in the value of B2B relationships (Ryssel, Ritter et al. 2004). They found, based on interviewing 61 German firms, that information technology deployment on interorganizational buyer-seller relationships has different effects on relationships and their value. Alba, Lynch et al. examined the implications of electronic shopping for consumers, retailers, and manufacturers. They assume that near-term technological developments will offer consumers unparalleled opportunities to locate and compare product offerings. They examine the advantages of e-marketplace, locate and compare product offerings, as a function of typical consumer goals and the nature of products and services being sought. They found industry structures influence the competition among retailers, competition among manufacturers, and retailer-manufacturer relationships (Alba, Lynch et al. 1997). While these studies did not specifically discuss the effect of different transaction mechanisms, their findings support the argument that the choice of e-commerce transaction mechanisms may be relational specific to context.

\subsection{Ease Of Switching}

In general, e-commerce, including both EDI and e-marketplace, can help reduce transaction cost by reducing the cost, delay and errors when the clerical processing of orders is automated electronically (Bensaou 1997). EDI further helps firms to improve efficiency of operation through reducing the cost of communicating with counterparts regarding transaction details (Lucking-Reiley and Spulber 2001).

However, EDI participants have relatively higher transaction specific assets compared to that of emarketplace participants. This is because EDI systems require its participants to retain technicians handling information systems, to invest in new or additional hardware or software, and sometime to modify operating procedures (Bakos and Treacy 1986). This investment therefore becomes a switching cost for participants, since the investment is lost when a firm discontinues its relationship with EDI creator (Heide and John 1990). 
The implementation process can be complicated. Firms often cited the implementation problem as a barrier to participate in EDI (Brenner and Hamm 1996). However, successful EDI participants develop their buyer-supplier relationships during the implementation process as they learn to understand the requirements of their exchange partners (Fearon and Philip 1998). Thus, the transaction specific assets and learning curve occurred during the process of implementing EDI contributes to maintaining existing inter-firm relationships.

Unique information and service exchanging through EDI are a great value to exchange parties. However, such exchanges require idiosyncratic changes for exchange parties, and the changes increase cost of switching to a competitor (Bakos and Treacy 1986). Higher switching costs by EDI participants cause the difficulty of joining the EDI by unaffiliated parties; by establishing enduring patterns of repeat trading, networks restrict access. Network such as EDI dictates the adoption of a particular technology, so it is more difficult for unaffiliated parties to join the network (Powell 1990). Opportunities are thus foreclosed to newcomers, either intentionally or more subtly through such barriers as unwritten rules or informal codes of conduct.

E-marketplace transactions are usually conducted via Internet. So the investments on information technology (i.e. transaction specific assets) to participate in an e-marketplace is relatively little among participants compared to participants of EDI. E-marketplace also reduces searching costs by assisting firms to find exchange partners in a market setting and making price and product comparisons (Lefebvre and Lefebvre 2000; LuckingReiley and Spulber 2001).

Participants of an e-marketplace can replace current exchange partners easily because of the low switching costs and the openness of the e-marketplace due to low transaction specific assets and ease of finding new partners (Grewal, Comer et al. 2001). Thus, the relationship between exchange parties can be limited to a single transaction and the buyer-supplier relationship is unstable.

\subsection{Level Of Information Sharing}

EDI enables exchange parties to share product and operational information such as price and delivery date frequently. Overtime, such information sharing over EDI can help exchange parties to understand their partners. Powell (Powell 1990) found that exchange parties trust information that comes from partners they know well. Thus, EDI creates a structure generating reliable information.

Sharing reliable information between buyers and suppliers can dramatically reduce indirect costs such as inventory levels and direct costs such as order entry or receipt throughout the entire industry value chain (Johnston and Vitale 1988; Westland and Clark 1999; Krishnbamurthy 2002; Lin, Lo et al. 2006). In this case, frequent updates on market demand for a specific product can help suppliers to manage the volume of supplying parts, which reduce inventory of the buyers.

While it is equally important to share reliable information among e-marketplace participants (Lyer, Singh et al. 2005; Wietrzyk, Wietrzyk et al. 2005), information sharing activities among participants of e-marketplace occurs at a different level from that of EDI participants. E-marketplace participants typically share information sufficiently to define the contractual agreements (Kaplan and Sawhney 2000). But ease of switching of exchange partners cautions participants to share information that may be considered sensitive, such as real time demand or performance data (Chen and Meixell 2003). The nature of discrete exchange also does not motivate participants to share information frequently to enable a better understanding of the partners for future exchanges.

\subsection{Governance}

EDI generates bilateral governance between exchange parties. Bilateral governance is based on the process of mutual adjustment to take care of uncertain environments (Noordewier, John et al. 1990). According to social exchange theory, a party's dependence on its partner leads to the partner's power in the dyadic relationship with its partner. Thus, power is the degree to which one party can influence another party to undertake an action (Emerson 1962; Cook and Emerson 1978). 
Since EDI participants depend on the EDI network creator, the network creator has a power over the participants. On the other hand, since it is more difficult for previously unaffiliated parties to join an existing network, the creator depends on participants. As the relationship with the sponsor moves from periphery to core of the participant's business, the relationship becomes more significant to the participant. Thus, it becomes more difficult for a potential competitor to displace the network creator (Johnston and Vitale 1988). Thus, interdependence between network creator and participants increases, as the exchange goes on. Both parties' symmetric and high interdependence is lead to bilateral governance (Heide 1994).

Bilateral governance possesses strength of reducing governance costs such as monitoring costs (Grandori 1987; Grandori 1997). Monitoring is checking the quality of products, delivery schedule or on-time delivery. The economization of monitoring costs could be due to the EDI's characteristic of ample information exchange. Information technology can improve the generation and evaluation of alternatives, so exchange parties can economize on monitoring costs (Bakos and Treacy 1986; Powell 1990).

Discrete transactions and unstable relationships are the unique characteristics of market governance (Heide 1994). Participants of e-marketplace are less likely to depend on their partners (Steinfield, Chan et al. 2000), so they rarely have a motivation to follow their partners' request (Axelrod 1984). Thus, the e-marketplace provides little foundation upon which a power structure develops and an exchange party has little control over the activities of a partner (Noordewier, John et al. 1990).

On the other hand, the low switching cost of e-marketplace does create competition among the suppliers, or among the buyers (Alba, Lynch et al. 1997; Bensaou 1997). Together with the open characteristics of an emarketplace, buyers can find low cost producers and suppliers can find the best offers easily.

\subsection{Control}

Buckley and Casson suggested that the sharing of information often leads to the emergence of common values (Buckley and Casson 1988). Thus, the repeated information exchange via EDI becomes a routine procedure in which exchange parties develop common values or relational norms (Macneil 1980; Gundlach and Achrol 1993). Since EDI extend the relationship into the future, the expectation of future exchange stimulates exchange parties to observe norms developed by the repeated relationship (Axelrod 1984).

By definition, relational norms constitute relevant behavior that socially prescribes an exchange parties' behavior. A shared set of implicit norms developed between exchange parties regulates the activities of the parties (Weitz and Jap 1995). Thus, relational norms provide order to ambiguous situations. Relational norms direct exchange parties to keep a certain level of limitation with which they may search for alternative ways to achieve their goals. Since relational norms prescribe appropriate behavior, they act as a control mechanism for exchange parties (Heide and John 1992). A degree of self control is achieved by relational norms.

EDI networks enable participants to share information frequently. Each party learns and understands the internal and external environments of the other through repeated transactions. This enables the development of relational norms among participants that produce voluntary efforts for mutual benefits between them. Thus, they produce better coordination and stability in the relationship (Gundlach and Achrol 1993).

Relation norms developed by EDI are another cause for exchange parties to be less likely to depend on monitoring (Heide 1994). Thus, the exchange parties self control to achieve mutual benefits. One example of this self control is the parties' mutual adjustment in a changing environment by showing flexible behavior (Heide 1994).

While there is market governance in an e-marketplace, if exchange parties do not expect future exchange, the motivation of suppliers to control product quality or on-time delivery is low. Thus, exchange parties in an emarketplace can not rely on partner's self control. Buyers and suppliers have to resort to a contractual agreement which is usually the only tool that guides their activities of partners (Palay 1984). 
In order to enforce contractual agreements, exchange parties emphasize reactive measurements on monitoring outputs and behaviors. These can only be assessed after the transaction is completed, such as monitoring product quality or on-time delivery when a product is delivered to the buyer (Heide 1994). So e-marketplace buyers can suffer from high monitoring costs to prevent opportunistic behaviors.

\section{FACTORS INFLUENCING CHOICE ON TRANSACTION MECHANISMS}

\subsection{Environmental Uncertainty}

Environmental uncertainty is defined as the extent that uncertainty decreases as an industry matures; the benefits that accrue to integration presumably decline (Williamson 1979). Exchange parties can feel uncertain when they do not have enough information for achieving their goals. Thus, an information exchange between parties is a better way to deal with uncertain problems (Powell 1990). Uncertainty increases the need for reliable information consistently over time. Exchange parties therefore possess a need to share information under the conditions of uncertainty (Powell 1990). Next, we define three sources of uncertainties, environmental dynamism, technology uncertainty, and environmental diversity.

Environment dynamism (consumer demand uncertainty) is defined as the frequency of change in consumer demand for a manufacturer's product (Hough and White 2003; Joshi and Campbell 2003). Information exchanges between a buyer and its supplier about changes in customer tastes or sudden infections help them to quickly bring the appropriate product to the market and adjust product features to meet market demand (Krishnbamurthy 2002). Thus, EDI helps exchange parties to reduce uncertainty in consumer demand. In addition to the information exchange, the relational norm should guide the supplier to a flexible response towards the buyer's request. For instance, when demand on a buyer's product soars, the suppliers with EDI can actively respond to the surge of demand from the buyer. Thus, though EDI cannot directly reduce consumer demand uncertainty, the relational norm developed through EDI is likely to buffer the uncertainty.

Technological uncertainty is defined as the degree at which focal product features and technologies are changing (Heide and Weiss 1995). Technological uncertainty motivates a buyer to increase search efforts to obtain new information (MacCrimmon and Taylor 1976). High degrees of technology uncertainty can creates huge information needs.

Network forms of organization are more likely to proliferate to the extent that exchange parties need information to innovate (Powell 1990). EDI may allow buyers and suppliers to share information on changes in product features and technology more quickly. However, current forms of EDI and an e-marketplace are not designed for product development process. Thus, neither of them will help participants in the case of high technological uncertainty.

Environmental Diversity is defined as the extent of dissimilarity between different environmental factors that buyers face (Achrol and Stern 1988; Klein, Frazier et al. 1990). Exchange parties facing a diverse environment have to deal with more diverse resource requirements, which increases their information needs (Galbraith 1977; Klein, Frazier et al. 1990).

A party with greater information requirements develops mechanisms to deal with the information, such as an increasing capacity to handle the information (Galbraith 1977). Close and frequent interaction between parties who are related to the required information increases information-processing capacity. Since EDI enables close and frequent interaction between parties, environmental diversity leads to the development of the EDI system. On the other hand, relying on the e-marketplace cannot solve the problem of obtaining the information in time. Thus, as environmental diversity increase, exchange parties are less likely to depend on the e-marketplace.

\subsection{Environmental Concentration}

Environmental concentration is defined as the extent to which a buyer perceives that resources are controlled by a few suppliers (Aldrich 1979; Achrol and Stern 1988). High environmental concentration means few 
suppliers provide most of its resources to many manufacturers. Due to the high cost and complexity of EDI implementations, suppliers have little motivation to participate in EDI when environmental concentration is high.

E-marketplace can only provide a limited advantage in help searching for the lowest cost supplier if there are only a few suppliers supplying a unique product. Thus, buyers will rely less on the e-marketplace when environmental concentration is high.

\subsection{Complexity Of Product Features}

Complexity of product features refers to the amount of information needed to specify the attributes of a product to allow buyers to make a selection (Malone, Yates et al. 1987; Mahadevan 2003). Bakos found that, in the market characterized by heterogeneous product offerings, buyer search costs can result in substantial inefficiencies (Bakos 1997). In general, an information network system provides the buyer with advantages of getting all the necessary information timely (Johnston and Vitale 1988). High complexity of a product feature implies more information requirement to specify the product accurately. Buyers are more likely to rely on EDI to resolve the information needs when the product feature is highly complex. Because of the relational norm characteristic, the EDI network also allows buyers and suppliers to collaborate closely when product features evolve over time.

When a product is not unique and easily described in standardized terms (commoditized products), buyers are likely to rely on electronic markets (Malone, Yates et al. 1987). Powell argues that exchange parties are more likely to obtain commoditized resources through short-term market transactions (Powell 1990). Thus, buyers who need commoditized products can take full advantage of the market competition of e-marketplace since standardized product features allow easy comparison among suppliers in an e-marketplace.

\subsection{Information Technology Capability}

Information technology capability is the degree to which exchange parties can carry out e-commerce. EDI requires participants to possess a high level of information technology and the capability of maintaining such technology. Thus, when exchange parties already have a high level of technology capability, they are more likely to rely on EDI to take advantage of such capability.

Participating in an e-marketplace requires little transaction specific investment and maintenance cost. Thus, exchange parties with low IT capacity are more likely to rely on the e-marketplace.

\section{EFFECTS FROM CHOICE OF TRANSACTION MECHANISM}

What are the effects of EDI and e-marketplace mechanisms on firms given the characteristics of the two transaction mechanisms and the influencing factors we have discussed?

\subsection{Opportunism}

Opportunism is defined as self-interest seeking behavior with guile (Williamson 1975). Opportunistic behaviors arise when an exchange partner has the opportunity to promote self-interest at the expense of its counterpart. Powell stated that exchange parties' desire for continuing relationships is likely to discourage opportunistic behavior (Powell 1990). In the context of e-commerce transactions, examples of opportunistic behaviors are poor quality products from a supplier, or refusal of payment by a buyer after receiving payments. Since opportunism from a partner will result in undesirable outcomes for its counterpart, engaging in opportunistic behaviors will likely terminate the current business relationship.

The EDI mechanism reduces the likelihood of opportunist behaviors in two ways. To the extent that networks make it easier to monitor the behavior of exchange partners such as checking to see if production or delivery schedules are proceeding as promised, the opportunistic behavior of the partner is prohibited (Steinfield, Kraut et al. 1995; Steinfield, Chan et al. 2000). The extensive information exchange between the parties improves 
monitoring capability (Gurbaxani and Whang 1991). Thus, the more information exchange between exchange parties, the less opportunistic behavior parties engaged in.

There is also less likelihood promoting self-interest in the event of termination of the EDI relationship because of the transaction specific assets participants invested in. Thus, the high level of transaction specific investments involved in EDI should reduce opportunistic behaviors from participants.

E-marketplace participants have less information sharing activities and little transaction specific investment. Thus, there are more opportunities and fewer penalties when one engages in opportunism. While contractual agreements should deter opportunism to a degree, this is true for e-marketplace as well as EDI participants (Herring and Milosevic 2001). Furthermore, since contracts are not perfect to cover all contingency, there is room for selfinterest seeking behaviors. Thus, e-marketplace participants are more vulnerable than EDI participants to opportunistic behavior of their partners.

\subsection{Long Term Orientation}

Long-Term Orientation is the tendency of exchange parties to gain benefits in the long run (Ganesan 1994). Since EDI requires a significant amount of transaction specific investments such as hiring technical personnel for managing information technology and installing facilities such as computer and software, EDI participants need to recover the investment. Since it takes time to recover these investments, exchange parties need to maintain longterm, locked-in relations with their partners (Steinfield, Kraut et al. 1995).

E-marketplace requires little transaction specific investments from participants. Thus, exchange parties risk little switching cost when they discontinue relationships with their current partners. They can replace the current partner whenever they find a good partner who offers a better deal. Thus, parties engaging in an e-marketplace transaction do not necessarily imply a future trading relationship. Participants therefore have short-term orientation in the relationship with their partner.

\subsection{Trust}

Trust refers to a willingness to rely on an exchange partner in whom one has confidence (Moorman, Zaltman et al. 1992; Moorman, Deshpande et al. 1993). Trust between buyers and supplier are important for both EDI and e-marketplace participants (McKnight, Choudhury et al. 2003; Pavlou and Gefen 2004). There are many studies on the issue of trust in marketing, supply chain management, and e-commerce literature (Aulach, Kotabe et al. 1996; Deeter-Schmelz and Kennedy 2004; Kwon and Suh 2004; Ryssel, Ritter et al. 2004; Lin, Lo et al. 2006). We only present a brief discussion here specifically related to e-commerce for our purpose.

The real challenge in implementing EDI is developing trust between exchange parties. Although there are clearly risks involved in entering into these information partnerships, the benefits that result from the network can be quite attractive (Westland and Clark 1999). EDI enables and requires exchange parties to share reliable information frequently. This leads to a stable relationship based on relational norms. It is difficult for exchange parties to opportunistically behave due to ample information exchange. The Security and stability promote understanding between exchange parties and generates trust (Powell 1990).

Trust between buyers and suppliers is more important for e-marketplace participants. However, it is difficult to develop trust since each party does not have any chance of developing trust in a discrete exchange (Gefen 2000; Pavlou 2002; Deeter-Schmelz and Kennedy 2004; Pavlou and Gefen 2004). Trust also contributes to the limited sharing of sensitive information among e-marketplace participants. It is worth it to mention that, Covisinct, an automobile website, only allows part suppliers who are recommended (or trusted) by a manufacturer.

Because of this difficulty, e-marketplace participants rely on size and reputation of other participants to assess their trustworthiness (Pavlou and Ba 2000). Size of a supplier conveys information on its motivational investment in being in business. When a large supplier fails to keep its promise, the penalty would be greater than those with smaller size (Jarvenpaa and Tractinsky 1999). Supplier reputation refers to the extent to which firms and 
people in the industry believe a supplier is honest and concerned about its customers (Doney and Cannon 1997). Williamson argues that reputations reduce incentives of opportunistic behavior in the inter-firm relationship (Williamson 1991). Ganesan (1994) showed that a supplier's good reputation increases buyer's trust in the supplier.

\section{DISCUSSION}

EDI transaction mechanism is characterized by a low ease of switching rich and frequent information sharing. This leads to bilateral governance and self control among EDI participants. On the other hand, emarketplace transaction mechanism is characterized by a high ease of switching and limited information sharing. This leads to market governance and contractual control among e-marketplace participants.

Even though EDI requires high transaction specific assets and complicated implementation processes, firms may still choose to participate in EDI under some conditions. According to existing studies, firms with more complex product features and greater information technology capability will be more likely to benefit more from EDI than e-marketplace. Frequent sharing of reliable information, bilateral governance and self control contribute to a greater capability for EDI exchange partners to collaborate on transactions involving products with complex features. Greater information capability lowers a firm's investment to participate and lowers its cost to maintain EDI.

In a business environment with a high level of environmental uncertainty, firms will benefit more from EDI than e-marketplace (except in the case of technological uncertainty). Environmental uncertainty increases a firm's information requirement to deal with the uncertainties. All studies that cover this issue suggest that the benefit is rooted in the frequent sharing of reliable information enabled by EDI networks. Frequent sharing of reliable information and the relational norm evolved from such sharing, enable partners to better buffer high consumer demand uncertainty (environment dynamism) and improve information processing capacity to manage environmental diversity.

E-marketplace offers little benefits when firms face high environment uncertainty because of the limited information exchange among participants. The main benefit of e-marketplace is rooted in the ease of switching. Participating in an e-marketplace requires lower switching costs (transaction specific investment) and a lower need for technological skills than participating in EDI. However, e-marketplace participants suffer from greater monitoring costs as a result of greater likelihood of opportunism among participants.

We have summarized past studies on EDI and e-marketplace based on their mechanism and influencing factors. While the existing findings cover a complex array of issues for managers to consider, only some of them have a significant impact on choosing transaction mechanisms. For example, though e-marketplace participants may incur greater monitoring costs, e-marketplace participants should still enjoy lower upfront investments than EDI participants. So the immediate cost of e-marketplace transactions should still be lower than EDI transactions. Thus, we reduce the choice of EDI and e-marketplace to an issue of fit along the short-term operational needs and long term strategic concerns.

From the operational perspective, we conclude that firms should choose e-marketplace mechanisms as long as it satisfies the minimum requirements of information sharing to specify procurement requirements. Procurement requirements include product and demand specifications, such as product type and quantity. As long as this is satisfied, firms can enjoy the low upfront investment to benefit from e-marketplace with the ease of switching in the future. Since firms should be able to identify procurement requirements with ease, it should be relatively easy to identify opportunities for using the e-marketplace to save cost.

The matter of strategic consideration is more complex because firms have to consider future trends. Procurement requirements become more complex as environmental uncertainties or product complexity increase. When these requirements become more complex, the structure of information exchange in an e-marketplace can quickly be overloaded. So procurement via e-marketplace becomes infeasible or problematic. In these situations, EDI transactions will perform better than e-marketplace transactions. For firms currently using e-marketplace transactions, they can switch to EDI transactions when environmental uncertainties or product complexity increase. 
It is easier for firms to assess current procurement requirements than to foresee future changes in environment uncertainties. Choosing e-marketplace transactions to satisfy current needs is a safer decision. On the other hand, firms may make a strategic choice to use EDI transactions if firms foresee significant increases in environmental uncertainties or product complexity. In this situation, firms should commit to EDI transactions long before these phenomenon's take place in order to establish the relational norms.

In the future, advancement in information technology may reduce the cost of deploying and maintaining information networks that enable the sharing of rich and reliable information more frequently. How will this affect a firm's choice on transaction mechanisms? Existing literature on switching cost and relational norms suggest that there may be a migration of e-marketplace participants to EDI networks.

A reduction on transaction specific investments should encourage more firms, who previously found the cost of EDI participation prohibitive, to join EDI networks. As we have found, EDI participants benefit from sharing rich and reliable information more frequently than e-marketplace participants. This allows firms to better manage environmental uncertainties and procurement complexity.

Enabling sharing of rich and reliable information frequently without increasing the cost of participation will certainly benefit e-marketplace participants as well. They could now improve their capability in managing environmental uncertainties and procurement complexity. On the other hand, sharing rich and reliable information frequently has limited benefits for e-marketplace participants whose transactions are discrete in nature. A key benefit of frequent information sharing over time is to develop relational norms that lead to bilateral governance and self control among EDI participants and to consequently reduce monitoring cost. However, firms with discrete transactions will not benefit from this characteristic. So, there remain the challenges of opportunism, lack of longterm orientation, and trust, among e-marketplace participants.

Information exchange between the buyer and supplier is an important aspect of supply chain management. B2B e-commerce helps firms to share information, maintain relationships, and conduct transactions more efficiently. The choice of B2B e-commerce transactions will influence, and as well as affect, the relationships between exchange parties. Thus, the choice of e-commerce transaction mechanisms has a relational context.

Appropriate choice of transaction mechanisms can affect a firm's strategy, procurement decisions, and performance. In this paper, we examine a collection of diverse studies on EDI and e-marketplace from marketing and information systems literatures. We offer a summary of implications from these findings for managers considering choices on e-commerce transaction mechanisms. We hope that this will provide managers a more consistent understanding of buyer-supplier relationships in the B2B e-commerce context.

\section{AUTHOR INFORMATION}

Dr. Ryu is an associate professor of school of business at Sungkyunkwan University. He specializes in the areas of channels of distribution, business-to-business marketing, and global supply chain management. He has publications in Industrial Marketing Management, Journal of Business Research, Organization Science, Journal of Business and Industrial Marketing, Journal of Business-to-Business Marketing, and Journal of Marketing Channels, and others.

Dr. Kuo-Ting Hung is an assistant professor of operations management at Suffolk University. He received his PhD in Industrial and Operations Engineering from the University of Michigan, Ann Arbor. Dr. Hung specializes in the research areas of supply chain operations and relationship management. His current research examines the role of agent behavior in operations management, decision-making in supply chain logistics and new product development process, and variations in healthcare service supply chain. Dr. Hung has published in IEEE Transactions on Engineering Management, Production Planning \& Control, Journal of Business and Management, International Journal of Industrial and Systems Engineering, and others. 


\section{REFERENCE}

1. Achrol, R. and L. Stern 1988. Environmental Determinants of Decision-Making Uncertainty in Marketing Channels. Journal of Marketing Research 25(1): 36-50.

2. Alba, J., J. Lynch, B. Weitz, C. Janiszewski, R. Lutz, A. Sawyer and S. Wood 1997. Interactive Home Shopping: Consumer, Retailer, and Manufacturer Incentives to Participate in Electronic Marketplaces. Journal of Marketing 61(3): 38-53.

3. Aldrich, H. 1979. Organizations and environments, Prentice-Hall Englewood Cliffs, NJ.

4. Aulach, P. S., M. Kotabe and Sahay 1996. Trust and Performance in Cross-Border Marketing Partnerships: A Behavioral Approach. Journal of International Business Studies(Special Issue): 1032 - 1005.

5. Axelrod, R. 1984. The Evolution of Cooperation+, New York: Basic Books.

6. Bailey, J. and Y. Bakos 1997. An Exploratory Study of the Emerging Role of Electronic Intermediaries. International Journal of Electronic Commerce 1(3): 7-20.

7. Bakos, J. 1997. Reducing Buyer Search Costs: Implications for Electronic Marketplaces. Management Science 43(12): 1676-1692.

8. Bakos, J. and M. Treacy 1986. Information Technology and Corporate Strategy: A Research Perspective. MIS Quarterly 10(2): 107-119.

9. Bakos, Y. 1998. The emerging role of electronic marketplaces on the Internet. Communications of the ACM 41(8): 35-42.

10. Bensaou, M. 1997. Interorganizational Cooperation. Information Systems Research 8(2): 107-124.

11. Bensaou, M. 1999. Portfolios of buyer-supplier relationships. Sloan Management Review 40(4): 35-44.

12. Boyle, B. and L. Alwitt 1999. Internet use within the US plastics industry. Industrial Marketing Management 28(4): 327-341.

13. Brenner, W. and V. Hamm 1996. Information technology for purchasing in a process environment. European Journal of Purchasing \& Supply Management 2(4): 211-219.

14. Buckley, P. J. and M. Casson 1988. A Theory of Cooperation in International Business. Cooperative Strategies in International Business. F. J. Contractor and P. Lorange. Lexington, MA, Lexington Books: pp. 31-53.

15. Cannon, J. and W. Perreault Jr 1999. Buyer-Supplier Relationships in Business Markets. Journal of Marketing Research 31(4): 439-460.

16. Chen, M. and M. Meixell 2003. Web Services Enabled Procurement in the Extended Enterprise: An Architectural Design and Implementation. Journal of Electronic Commerce Research 4(4): 140-155.

17. Cook, K. and R. Emerson 1978. Power, Equity and Commitment in Exchange Networks. American Sociological Review 43(5): 721-739.

18. Dai, Q. and R. J. Kauffman 2002. B2B E-Commerce Revisited: Leading Perspectives on the Key Issues and Research Directions. Electronic Markets 12(2): 67-83.

19. Deeter-Schmelz, D. and K. Kennedy 2004. Buyer-seller relationships and information sources in an ecommerce world. Journal of Business \& Industrial Marketing 19(3): 188-196.

20. Doney, P. and J. Cannon 1997. An Examination of the Nature of Trust in Buyer-Seller Relationships. Journal of Marketing 61(2): 35-51.

21. Dyer, J., D. Cho and W. Chu 1998. Strategic supplier segmentation: the next best practice in supply chain management. California Management Review 40(2): 57-77.

22. Emerson, R. 1962. Power-Dependence Relations. American Sociological Review 27(1): 31-41.

23. Fearon, C. and G. Philip 1998. Self assessment as a means of measuring strategic and operational benefits from EDI: the development of a conceptual framework. European Journal of Information Systems 7: 5-16.

24. Galbraith, J. 1977. Organization design, Addison-Wesley Pub. Co Reading, Mass.

25. Ganesan, S. 1994. Determinants of Long-Term Orientation in Buyer-Seller Relationships. Journal of Marketing 58(2): 1-19.

26. Gefen, D. 2000. E-commerce: the role of familiarity and trust. Omega 28(6): 725-737.

27. Grandori, A. 1987. Perspectives on organization theory, Ballinger Pub. Co Cambridge, Mass.

28. Grandori, A. 1997. Governance Structures, Coordination Mechanisms and Cognitive Models. Journal of Management and Governance 1(1): 29-47.

29. Grewal, R., J. M. Comer and R. Mehta 2001. An investigation into the antecedents of organizational participation in business-to-business electronic markets. Journal of Marketing 65(3): 17-33. 
30. Grieger, M. 2003. Electronic marketplaces: A literature review and a call for supply chain management research. European Journal of Operational Research 144(2): 280-94.

31. Gundlach, G. and R. Achrol 1993. Governance in exchange: contract law and its alternatives. Journal of Public Policy and Marketing 12(2): 141-55.

32. Gurbaxani, V. and S. Whang 1991. The impact of information systems on organizations and markets. Communications of the ACM 34(1): 59-73.

33. Heide, J. 1994. Interorganizational Governance in Marketing Channels. Journal of Marketing 58(1): 71-85.

34. Heide, J. and G. John 1990. Alliances in Industrial Purchasing: The Determinants of Joint Action in BuyerSupplier Relationships. Journal of Marketing Research 27(1): 24-36.

35. Heide, J. and A. Weiss 1995. Vendor Consideration and Switching Behavior for Buyers in HighTechnology Markets. Journal of Marketing 59(3): 30-43.

36. Herring, C. and Z. Milosevic 2001. Implementing B2B contracts using BizTalk. System Sciences, 2001. Proceedings of the 34th Annual Hawaii International Conference on: 10.

37. Hough, J. and M. White 2003. Environmental dynamism and strategic decision-making rationality: An examination at the decision level. Strategic management journal 24(5): 481-489.

38. Jarvenpaa, S. and N. Tractinsky 1999. Consumer Trust in an Internet Store: A Cross-Cultural Validation. Journal of Computer-Mediated Communication 5(2): 1999.

39. Johnston, H. and M. Vitale 1988. Creating Competitive Advantage with Interorganizational Information Systems. MIS Quarterly 12(2): 153-165.

40. Joshi, A. and A. Campbell 2003. Effect of Environmental Dynamism on Relational Governance in Manufacturer-Supplier Relationships: A Contingency Framework and an Empirical Test. Journal of the Academy of Marketing Science 31(2): 176-188.

41. Kaplan, S. and M. Sawhney 2000. E-hubs: The New B2B Marketplaces, Harvard Business Review.

42. Kaufman, A., C. Wood and G. Theyel 2000. Collaboration and technology linkages: a strategic supplier typology. Strategic Management Journal 21(6): 649-663.

43. Klein, S., G. Frazier and V. Roth 1990. A Transaction Cost Analysis Model of Channel Integration in International Markets. Journal of Marketing Research 27(2): 196-208.

44. Krishnbamurthy, S. 2002. E-Commerce Management: Text and Cases. Mason, Ohio, Southwestern.

45. Kwon, I. and T. Suh 2004. Factors Affecting the Level of Trust and Commitment in Supply Chain Relationships. Journal of Supply Chain Management 40(2): 4-14.

46. Lancioni, R., M. Smith and T. Oliva 2000. The Role of the Internet in Supply Chain Management. Industrial Marketing Management 29(1): 45-56.

47. Lefebvre, L. and E. Lefebvre 2000. Virtual enterprises and virtual economy: manifestations and policy challenges. International Journal of Technology Management 20(1): 58-71.

48. Lin, F., Y. Lo and Y. Sung 2006. Effects of Switching Cost, Trust, and Information Sharing on Supply Chain Performance for B2B e-Commerce: A Multi-agent Simulation Study. Proceedings of the 39th Annual Hawaii International Conference on System Sciences-Volume 06.

49. Low, B. 1996. Long-Term Relationship in Industrial Marketing-Reality or Rhetoric? Industrial Marketing Management 25(1): 23-35.

50. Lucking-Reiley, D. and D. Spulber 2001. Business-to-Business Electronic Commerce. The Journal of Economic Perspectives 15(1): 55-68.

51. Lyer, L., R. Singh and A. Salam 2005. Intelligent agents to support information sharing in B 2 B Emarketplaces. Information systems management 22(3): 37-49.

52. MacCrimmon, K. and R. Taylor 1976. Decision making and problem solving. Handbook of Industrial and Organizational Psychology, Rand McNally, Chicago, IL: 1397-453.

53. Macneil, I. 1980. The new social contract: an inquiry into modern contractual relations, Yale University Press.

54. Mahadevan, B. 2003. Making sense of emerging market structures in Business to Business E Commerce. California Manage. Rev 46(1): 86-100.

55. Malone, T., J. Yates and R. Benjamin 1987. Electronic markets and electronic hierarchies. Communications of the ACM 30(6): 484-497.

56. McKnight, D., V. Choudhury and C. Kacmar 2003. Developing and Validating Trust Measures for eCommerce: An Integrative Typology. Information Systems Research 13(3): 334-359. 
57. Moorman, C., R. Deshpande and G. Zaltman 1993. Factors Affecting Trust in Market Research Relationships. Journal of Marketing 57(1): 81-101.

58. Moorman, C., G. Zaltman and R. Deshpande 1992. Relationships between Providers and Users of Market Research: The Dynamics of Trust within and between Organizations. Journal of Marketing Research 29(3): 314-328.

59. Noordewier, T., G. John and J. Nevin 1990. Performance Outcomes of Purchasing Arrangements in Industrial Buyer-Vendor Relationships. Journal of Marketing 54(4): 80-93.

60. Palay, T. 1984. Comparative Institutional Economics: The Governance of Rail Freight Contracting. The Journal of Legal Studies 13(2): 265-287.

61. Pavlou, P. and D. Gefen 2004. Building Effective Online Marketplaces with Institution-Based Trust. Information Systems Research 15(1): 37-59.

62. Pavlou, P. A. 2002. Institution-based trust in interorganizational exchange relationships: the role of online B2B marketplaces on trust formation. Journal of Strategic Information Systems 11(3): 215-243.

63. Pavlou, P. A. and S. Ba 2000. Does Online Reputation Matter?-An Empirical Investigation of Reputation and Trust in Online Auction Markets. Proceedings of the AMCIS 2000 Conference.

64. Powell, W. 1990. Neither Market Nor Hierarchy: Network Forms of Organization. Research in Organizational Behavior 12: 295-336.

65. Raymond, L. and S. Blili 1997. Adopting EDI in a network enterprise: the case of subcontracting SMEs. European Journal of Purchasing and Supply Management 3(3): 165-175.

66. Roberts, B. and M. Mackay 1998. IT supporting supplier relationships: The role of electronic commerce. European Journal of Purchasing and Supply Management 4(2): 175-184.

67. Ryssel, R., T. Ritter and H. Gemünden 2004. The impact of information technology deployment on trust, commitment and value creation in business relationships. Journal of Business and Industrial Marketing 19(3): 197-207.

68. Sarkar, M., B. Butler and C. Steinfield 1998. Cybermediaries in Electronic Marketspace: Toward Theory Building. Journal of Business Research 41(3): 215-221.

69. Steinfield, C., A. Chan and R. Kraut 2000. Computer Mediated Markets: An Introduction and Preliminary Test of Market Structure Impacts. Journal of Computer Mediated Communication 5(3).

70. Steinfield, C., R. Kraut and A. Plummer 1995. The Impact of Interorganizational Networks on Buyer-Seller Relationships. Journal of Computer-Mediated Communication 1(3).

71. Weitz, B. and S. Jap 1995. Relationship marketing and distribution channels. Journal of the Academy of Marketing Science 23(4): 305-20.

72. Westland, J. and T. Clark 1999. Global electronic commerce, MIT Press Cambridge, Mass.

73. Wietrzyk, V., I. Wietrzyk and B. Grosky 2005. Web Based Electronic Marketplaces: Trading through Collaboration. Database and Expert Systems Applications, 2005. Proceedings. Sixteenth International Workshop on: 616-620.

74. Williamson, O. 1975. Markets and Hierarchies. New York, The Free Press.

75. Williamson, O. 1979. Transaction-Cost Economics: The Governance of Contractual Relations. Journal of Law and Economics 22(2): 233-261.

76. Williamson, O. 1991. Comparative Economic Organization: The Analysis of Discrete Structural Alternatives. Administrative Science Quarterly 36(2). 
NOTES 